\title{
Confronting Climate Change Challenges to Dryland Cereal Production: A Call for Collaborative, Transdisciplinary Research, and Producer Engagement
}

\author{
Sanford D. Eigenbrode ${ }^{1 *}$, W. Patrick Binns ${ }^{2}$ and David R. Huggins ${ }^{3}$ \\ ${ }^{1}$ Entomology, Plant Pathology and Nematology, University of Idaho, Moscow, ID, United States, ${ }^{2}$ Westbrook Associates \\ LLC, Seattle, WA, United States, ${ }^{3}$ United States Department of Agriculture-Agricultural Research Service, Washington State \\ University, Pullman, WA, United States
}

\section{OPEN ACCESS}

Edited by:

Luuk Fleskens,

Wageningen University and Research,

Netherlands

Reviewed by:

Richard James Thomas, International Center for Agricultural

Research in the Dry Areas, Syria

Anthony Michael Whitbread, International Crops Research Institute for the Semi-Arid Tropics (ICRISAT),

India

${ }^{*}$ Correspondence: Sanford D. Eigenbrode

sanforde@uidaho.edu

Specialty section:

This article was submitted to Agroecology and Land Use Systems,

a section of the journal

Frontiers in Ecology and Evolution

Received: 25 August 2017 Accepted: 05 December 2017

Published: 04 January 2018

Citation:

Eigenbrode SD, Binns WP and Huggins DR (2018) Confronting Climate Change Challenges to Dryland Cereal Production: A Call for

Collaborative, Transdisciplinary Research, and Producer Engagement.

Front. Ecol. Evol. 5:164.

doi: 10.3389/fevo.2017.00164
Semi-arid cereal systems face challenges worldwide that are driven by ongoing and projected climate change. These challenges include ensuring cropping system resilience and productivity under changing water and temperature regimes while reversing soil degradation, reducing crop susceptibility to pests, pathogens and weed competition, and exploiting genetic resources to develop cultivars with resilience to climate stresses and improved compatibility with cropping system innovations. Meeting these interdependent challenges requires transdisciplinary efforts that integrate knowledge across many scientific domains. The USDA-NIFA-funded coordinated agricultural project, "Regional Approaches to Climate Change for Pacific Northwest Agriculture" (REACCH), employed this transdisciplinary approach to address climate change and sustainability challenges for rain-fed cereal-based systems in the semi-arid intermountain Pacific Northwest. To engage with and contribute to similar efforts globally, REACCH sponsored a workshop "Transitioning Cereal Systems to Adapt to Climate Change" (TCSACC) in November 2015. Participants from 17 countries and five continents with expertise in agronomy, crop physiology, crop modeling, crop protection, breeding and genetics, sociology and economics shared their perspectives, successes, and challenges to achieving transdisciplinary research integration for semi-arid cereal systems under changing climates. Conference goals were to: (1) strengthen the global network of researchers addressing climate change effects on semi-arid cereal-based systems, (2) share the approaches to achieving transdisciplinary collaboration to advance climate change resilience in cereal systems, and (3) identify the elements of a collaborative research agenda that are needed to advance global food security in the twenty-first century. This paper distills the conference themes and summarizes the calls to action that were discussed: Establish coordinated, large scale, transdisciplinary efforts; Consider Genetic $\times$ Environment $\times$ Management $\times$ Social system $(G \times E$ $\times \mathrm{M} \times \mathrm{S}$ ) interactions; Integrate social, economic, and biophysical science, and 
engineering; Improve integration among knowledge communities; Consider global context of production systems; Develop more inclusive cropping system models; Enable comprehensive data management and data sharing; Include landscape and ecosystem services perspectives; Establish and support existing global collaboration networks.

Keywords: climate, resilient, cereals, transdisciplinary, research, collaboration, farmers, agroecology

\section{INTRODUCTION}

The challenges to achieving sustainable food security in the coming decades are daunting. The convergence of a rapidly growing global population, increasing consumption behaviors, and turbulent social, economic and geopolitical issues will impose difficult conditions for farmers everywhere. Additionally, increasing global land and ocean temperatures and increased frequency of extreme weather events are contributing to changing agroclimatic conditions throughout the world (Fuhrer, 2003; Kalra et al., 2007; FAO, 2011; Walthall et al., 2012; Collins et al., 2013; Mayer, 2013; Lobell and Tebaldi, 2014). The severity of these challenges has troubling implications for health and prosperity at household, community, regional, national and global scales.

Among the most vulnerable systems are cereal systems in semi-arid regions, which account for much of global food production. These include regions dominated by large scale industrial agriculture and others where small-holder production predominates (Lowder et al., 2016). These regions share vulnerability to fluctuations in precipitation and periods of elevated temperature that will present increasing challenges under climate change (Asseng et al., 2014; Challinor et al., 2014; Wilcox and Makowski, 2014). Some of the challenges are common to all systems, inviting collaboration to address them, while others are specific to regions, farming systems, and the social, economic, and ecological systems that support them. Identifying the common and unique challenges and finding solutions for local and regional conditions is a high priority to ensure global food security.

Cereal systems in semi-arid regions, like all food production systems, are social-ecological systems (SES), as such it is widely recognized that they can be productively studied within a broad framework that encompasses genetics, environment, management and social dimensions and their interactions $(\mathrm{G} \times \mathrm{E}$ $\times \mathrm{M} \times \mathrm{S}$ ) (Figure 1; Hatfield and Walthall, 2015; Tonnang et al., 2017). Hence, efforts to improve them must be transdisciplinary [Wickson et al., 2006; Francis et al., 2008; National Science Foundation (USA), 2015; Wigboldus et al., 2016], bridging traditional agricultural and related ecological, biogeochemical, hydrological, meteorological, social, and economic disciplines (Howden et al., 2007; Francis et al., 2008; Hatt et al., 2016). In addition, these efforts must engage food system stakeholders to incorporate their understanding of the opportunities, constraints, and risks involved in implementing adaptive farming practices. Stakeholder participation helps research arrive at tenable "best management practices" (BMP's), including "climate friendly BMPs" (cfBMP's) (Pan et al., 2017) that are more readily adopted (Schaap et al., 2013). These collaborations must encompass the temporal and spatial scales relevant to agricultural landscapes undergoing climate change to encompass the extent of these systems and the processes that affect them. Efforts to do so are underway in different parts of the world and their effectiveness could be improved by cross-project communication or coordination.

"Regional Approaches to Climate Change for Pacific Northwest Agriculture" (REACCH), was a seven-year collaborative effort by the University of Idaho, Washington State University, Oregon State University, and the United States Department of Agriculture (USDA) Agricultural Research Service, funded by the USDA National Institute of Food and Agriculture (NIFA). The project conducted trans-disciplinary research, education, and outreach focused on the cereal based systems of the inland Pacific Northwest (iPNW) under projected climate change. It aimed to improve knowledge of the production systems, identify opportunities to improve their efficiency and sustainability, promote farmer participation, provide decision support tools, educate producers and citizens at all levels. The conceptual framework, outputs and outcomes of the REACCH project can be accessed through its web site: https://www.reacchpna.org, and in publications, including some appearing in this special issue of Frontiers in Ecology and Evolution: (1) Develop a theoretical framework integrating cropping system, economic and climate modeling (Abatzoglou et al., 2014; Antle et al., 2017; Stöckle et al., 2017), (2) Monitor greenhouse gas (GHG) emissions and nitrogen and carbon dynamics in the production systems (Chi et al., 2016, 2017; Waldo et al., 2016; Kostyanovsky et al., 2017), (3) Compare current and aspirational production systems for productivity and GHG emission potential under current and projected climate (Pan et al., 2016, 2017; Brown et al., 2017; Maaz T. et al., 2017; Maaz T. M. et al., 2017; Stöckle et al., 2017), (4) Address the environmental, social, and economic factors influencing agriculture and technology adoption (Antle et al., 2017; Karimi et al., 2017; Kaur et al., 2017), (5) Anticipate climate change related changes in crop protection requirements (Davis et al., 2015a,b, 2017; Eigenbrode et al., 2015; Foote et al., 2017), (6) Work closely with producers to develop and guide project activities (Kruger and Yorgey, 2017; Yorgey et al., 2017), (7) Educate students from elementary through graduate levels to prepare coming generations for challenges related to climate change in agriculture (White et al., 2014), (8) Ensure data from the project and related projects are managed to facilitate detecting trends and interdisciplinary collaboration (Flathers et al., 2017), and (9) Coordinate all these activities under an integrated, transdisciplinary framework (Eigenbrode et al., 2014, 2017; Morton et al., 2015).

REACCH is a regional effort, but it is part of the global response to climate change effects on semi-arid cereal 


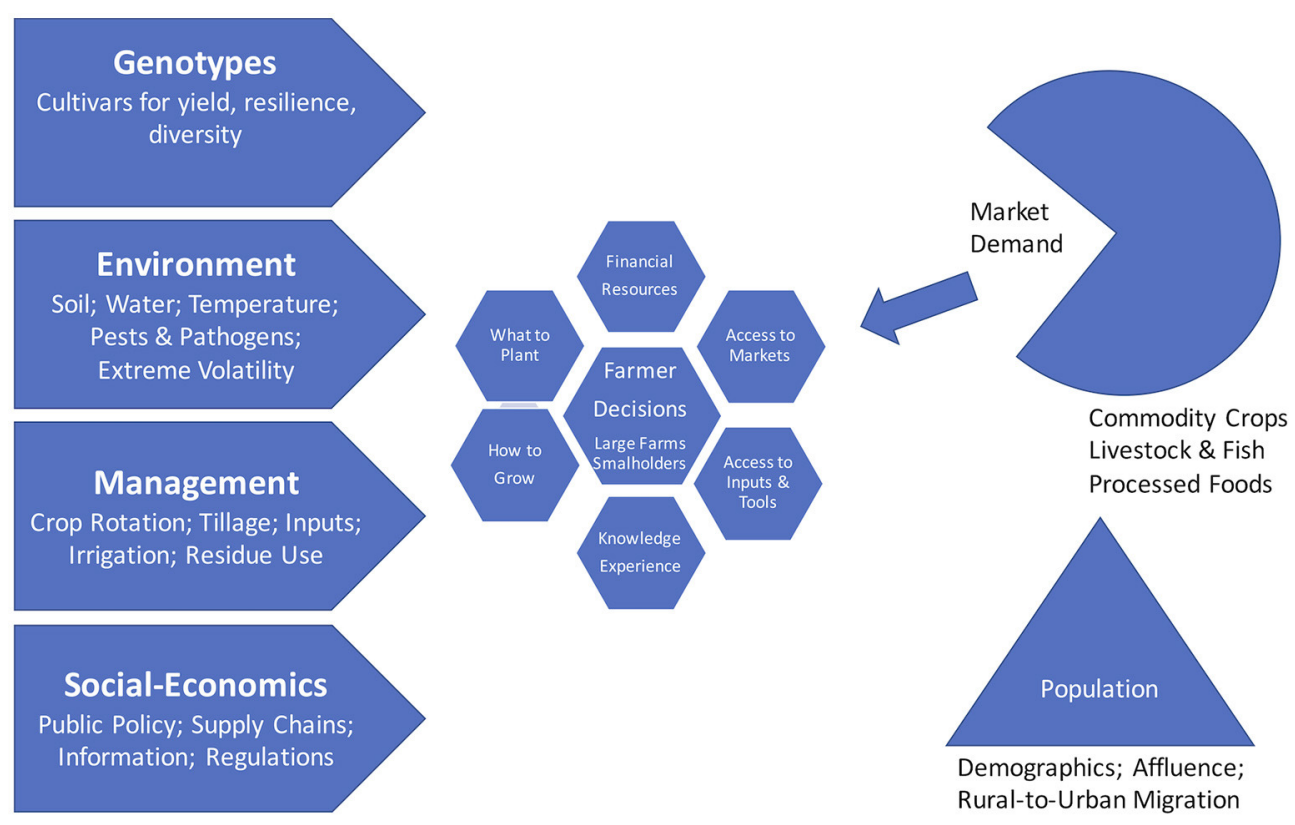

FIGURE 1 | Schematic representation of cereal production as a social-ecological system. The domains of environmental conditions of soil quality, precipitation, fresh water access, temperatures, pest pressures, and extreme weather events; genotype properties of cultivars, annuals, perennials, root structure; biological $\mathrm{N}$ fixing; stress tolerance; agronomic management of crop diversity, tillage, input use, livestock integration, residue retention, and social-economic factors that affect market demand, price signals, capital investment, public incentives, regulations, research; and cultural customs and attitudes all interact to establish the context, motivation, and resources that influence farmers' decisions concerning how to adapt to changing climate regimes.

production systems. Similar coordinated efforts are under way or needed everywhere and could benefit from communication, coordination, and collaboration. To help address this need, REACCH sponsored a workshop-style international conference, "Transitioning Cereal Systems to Adapt to Climate Change" (TCSACC), which preceded the 2015 combined annual meetings of the USA Tri-Societies (American Society of Agronomy, Crop Science Society of America, and Soil Science Society of America) and Entomological Society of America (Minneapolis, MN, Nov. 13-15). TCSACC convened 120 scientists from 17 countries on five continents, representing the major semiarid regions where cereals are produced. Participants included scientists from major universities and national research entities (CSIRO and Department of Environmental and Primary Industries, Australia, USDA-ARS, and NIFA, USA), CGIAR centers including CIMYYT, ICARDA, ICRISAT, ICIPE, and scientists within the CGIAR Climate Change, Agriculture and Food Security Research Program, the Chinese Academy of Sciences, and others. Conference goals were to: (1) strengthen the global network of researchers addressing climate change effects on semi-arid cereal-based systems, (2) share the approaches to achieving transdisciplinary collaboration to advance climate change resilience in cereal systems, and (3) identify the elements of a collaborative research agenda that is needed to advance global food security in the twenty-first century. Keynote addresses reviewed conditions and research efforts in semi-arid systems in North America, South America, Australia, Africa, India, and China. Concurrent breakout sessions addressed specific themes: Water resources and crop production, Cropping system improvements and innovation, Crop protection: pests, weeds, and pathogens, Genetic improvement and integration, Identifying and assessing adaptation strategies, Greenhouse gases: Monitoring and approaches to mitigation, Cropping system models as platforms for integration, Collaborative translational science to address climate change in semiarid systems, and Data management to enable regional and global efforts. Closing discussions sought to identify needs or continuing effort and opportunities for collaboration. Slide presentations, videos of keynotes, and notes from discussions, and short bios of all conference attendees can be accessed on the conference web site: https://aridcereals.nkn. uidaho.edu. This paper provides highlights of the conference and summarizes its conclusions and suggested action steps.

\section{RESEARCH THEMES TO ADDRESS CLIMATE CHANGE EFFECTS ON CEREAL SYSTEMS}

\section{Cropping System Improvements and Innovation to Address Water Scarcity}

Cereal production systems in semi-arid habitats are limited primarily by available water, which is projected to be exacerbated by climate change in many of regions where these systems occur (Hijmans et al., 2005; Fraser et al., 2013; IPCC, 2014). Agronomic adaptations to cope with water scarcity and drought have been utilized for millennia (e.g., Sandor 
et al., 1990). In some regions, alternating years of fallow allows cropping on limited precipitation. This has been the predominant practice, for example, for much of iPNW wheatbased dryland farming where nearly $25 \%$ of cereal systems are in annual fallow (NASS, 2015). However, reliance on annual fallow has significant limitations. If the fallow cycle does not provide adequate ground cover protection by residue mulch or standing stubble, it leaves the topsoil vulnerable to wind and water erosion (Singh et al., 2012), also annual fallow is extremely inefficient with respect to water conservation and results in poor overall water use efficiency (Hatfield et al., 2001). Another limitation of alternating fallow is that it is effectively a monoculture that restricts the use of non-cereal crops (e.g., legumes, "green manure" cover crops, oil seeds) and limits cropping system diversification and intensification important for breaking disease and pest cycles, improving soil properties, enhancing weed management, and helping with nutrient management through introduction of biological nitrogen-fixing species (Tilman, 1999; Kirkegaard et al., 2008; Maaz T. et al., 2017).

Contemporary practices such as prudent use of tillage and residue management (Kirkegaard et al., 2014), novel rotations (Whitbread et al., 2015), or "response farming" (Stewart and Faught, 1984) can help conserve water and increase water use efficiency on farms to help with current and anticipated chronic and episodic water limitation. In the $\mathrm{REACCH}$ project, for example, experimentation and modeling have examined viability of winter canola, winter legumes, and triticale as rotational crops in the lower rainfall regions of the iPNW (Maaz T. M. et al., 2017; Pan et al., 2017; Stöckle et al., 2017). Water conserving technologies examined have included use of alternative wheat harvesting equipment (e.g., stripper headers) that maximize post-harvest residue height, thereby trapping additional winter moisture, have also been included in this modeling analysis. In some settings, in situ or ex situ rainwater catchment during wet seasons may be improved to help bridge over dry periods (Kumar et al., 2016). Additionally, flex or opportunity cropping systems are in development as fallow replacement options when pre-plant precipitation and soil water storage are sufficient (Kaur et al., 2017).

Achieving sustainability will require farming methods that efficiently utilize non-renewable resources and leverage and contribute to ecosystem services that impart greater crop adaptive capacity and resilience to changing climates and environmental stress including water limitations (Reynolds and Langridge, 2016). Additional research is needed everywhere to identify and evaluate additional alternative rotational crops and agronomic practices to improve the efficiency of water use. Mid-term climate projections or forecasts are notoriously difficult, but if these are reliable, they can be used to allow farmers to make decisions about which crops to plant depending upon anticipated available water (Meinke and Stone, 2005; Doblas-Reyes et al., 2013). Availability of more economically viable crops or methods will enable this sort of adaptive management, or "flex cropping" (e.g., Kaur et al., 2017).

\section{Genetic Improvement and Integration}

Genetic resources are a foundation of successful production systems (Figure 1). Advances in breeding and genetics coupled with greatly increased application of chemical inputs (primarily synthetic nitrogen fertilizer), have significantly forestalled the global food security crises that had been envisioned in the late twentieth century. Ongoing population growth will require continued progress in increasing yields, but yield improvements must be coupled with improved tolerance to the abiotic and biotic stresses- related to climate change (e.g., Kole et al., 2015). New genomic tools for better understanding the physiological bases of plant responses to stress, responsiveness to $\mathrm{CO}_{2}$ fertilization, greater water and nitrogen use efficiencies, and especially heat and drought stress will enable this. In wheat, the USDA NIFAsponsored Triticeae Coordinated Agriculture Project (T-CAP) has organized and funded 56 participants in 28 institutions and 21 states and includes efforts to adapt wheat and barley for improved water use efficiency (WUE), nutrient use efficiency (NUE), and drought resistance. International efforts include the USAID Climate Change Resilient Development programfunded Climate Resilient Wheat (CRW) projects in Kazakhstan and India, the latter partnering with the Indian Council of Agricultural Research (ICAR)-Directorate of Wheat. These are multi-million-dollar efforts that promise rapid improvements in cereal grain adaptation to climate related stress.

In addition to these approaches to improving yield potential, there is wide recognition that improved global coordination and broader integration involving breeders, crop modelers and agronomists is needed to promote progress. Yield and quality performance results from the interactions of genetics, environment, and management $(\mathrm{G} \times \mathrm{E} \times \mathrm{M}$; Hatfield and Walthall, 2015), while approaches that are based on a single technological innovation in one of these areas can only provide partial success (Anderson et al., 2016). Since both breeding and agronomy were instrumental in the achievements of the green revolution, continued innovation will be required to meet these ongoing challenges (summarized in Anderson et al., 2005; in their review of ongoing work on yield gaps in Australia). Furthermore, ongoing yield advances must be accompanied by improved sustainability of the yield over many years and the ability to deliver multiple ecosystem services. For example, the CRW project in Kazakhstan adopted this integrating approach by investigating experimental plantings of drought resilient crops; alternative crop rotations; shifting from monoculture to diversified planting strategies; use of low-till and no-till farming methods; and accessing information from new weather forecasting technology.

Research gaps and needs identified in discussions at TCSACC and outcomes of the 2013 workshop sponsored by USAID and the Bill \& Melinda Gates Foundation (Reynolds and Langridge, 2016) include improved technology to enable genomic and highthroughput phenomic selection, emphasizing yield stability, and quality to complement yield targets, including more defined environmental effects in experimental designs, universal data sharing between projects, access to knowledge repositories including those from private companies, improving utilization of cropping system models in impact assessments and cultivar 
selection decision-making. Such cooperation would advance the accurate identification and focus on phenotypical traits that are most compatible with current and alternative production systems and crop rotations.

\section{Cropping System Models: Platforms for Integration and Data Harmonization}

Progress in developing cereal cultivars and designing and implementing cropping systems adapted to climate variability and extreme events will require integration of empirical and modeling approaches. This is because of the impracticality of conducting sufficient numbers of extensive empirical studies replicated across production landscapes that are variable in space and in time. Instead, improved approaches to develop virtual cropping system models coupled with more accurate and affordable sensors and field data acquisition systems to parameterize them is required, and it is achievable (Jones et al., 2016). The primary effort to compare and improve cropping systems modeling has been through the Agricultural Model Intercomparison and Improvement Project (AgMIP) (http:// www.agmip.org). Building on foundations laid by Heady (1957), Duncan et al. (1967), and Dent and Blackie (1979), the CERES crop models in the mid-1980's eventually were incorporated into widely used DSSAT (Hoogenboom et al., 2012) and APSIM (Holzworth et al., 2014). The cropping system model, CropSyst (Stöckle et al., 2003), also had its genesis in the early 1990's. With AgMIP's influence, continued improvement of cropping models has involved many disciplines to incorporate more factors and their variability with time and location. Cross-disciplinary improvements to agricultural modeling would greatly contribute to reducing the degree of uncertainty that confronts decision makers at all levels of the food production sector (Asseng et al., 2013). Significant gaps remain to be resolved (Jones et al., 2016), including incorporating pests, weeds, diseases, rotational effects, soil and nutrient variables, genetic variability, and episodic abiotic stresses. To enable this, support is needed for archiving research data and model outputs, with attention to interoperability, and common meta-tagging conventions for cross-validation, sharing, and creatively synthesizing modeling outputs, and supporting next generation modeling efforts (see www.agmip.org).

\section{Data Management to Enable Regional and Global Efforts}

Achieving the potential of crop modeling and collaborations that draw upon results of research underway globally will require improved access to data, including results from agronomic trials, effects of biotic and abiotic stresses, gridded output from simulation models, and data from social and economic surveys. Efforts to address cereal production systems worldwide are currently diminished by the inadequate capacity and capability of existing data repositories to host and support enhanced accessibility to these diverse data sets. In other words, the capacity for mobilizing "Big Data" for agriculture is sorely needed.

Work at the forefront to meet this need includes efforts by AgMIP, the USDA's Greenhouse Gas Reduction through
Agricultural Carbon Enhancement network (GRACEnet, https:// www.ars.usda.gov/anrds/gracenet/gracenet-home/; Jawson et al., 2005), the Global Research Alliance on Agricultural Greenhouse Gases (GRA) (with 46 participating countries; http://globalresearchalliance.org), the CGIAR, through its Data Management System within its Open Access Open Data initiative (http://www.cgiar.org/resources/open-access/), and the Global Wheat Initiative (http://www.wheatinitiative.org/). The consensus of TCSACC participants was that approaches are needed to acquire and manage diverse sorts of data pertinent to entire production systems and to share and compare these across semiarid systems and regions.

\section{Crop Protection: Pests, Weeds, and Pathogens}

Projections for cereal production systems under climate change typically are constructed without considering associated changes in pressure from insect pests, weeds and diseases (Coakley et al., 1999; Garrett et al., 2006, 2014; Juroszek and Von Tiedemann, 2013; Eigenbrode and Macfadyen, 2017). Attempts to incorporate disease and insect effects into model projections presents challenges because responses by individual pests, weeds, and diseases can arise from direct effects on agent physiology, behavior, and phenology that influence geographic range, reproduction and mortality impacts (Juroszek and Von Tiedemann, 2015). Drivers include seasonal warming and increasing atmospheric $\left[\mathrm{CO}_{2}\right]$ on pest fecundity and population dynamics (Dyer et al., 2013), shifts in geographic or elevational ranges of pests (Bebber et al., 2013; Bebber, 2015), expression of plant resistance factors affecting pests (Tyler and Hatchett, 1983; Currie et al., 2014), acceleration of pest resistance to pesticides and Bt (Bacillus thuringiensis) genetically engineered crops (Venugopal and Dively, 2017), changes to feeding behavior, phenology, and voltinism (Ziter et al., 2012), and alterations to trophic interactions and biological control mechanisms (Gillespie et al., 2013; Romo and Tylianakis, 2013; Eigenbrode et al., 2015).

A review of worldwide research on insect pests of wheat and climate change (Eigenbrode and Macfadyen, 2017) found research addressing only a dozen species, most of which had only been studied using a particular approach such as niche modeling, chamber studies, empirical study, and population modeling. For pathogens, the incidence, effectiveness of resistance genes and multispecies interactions are all liable to change in response to climate induced stress. The cumulative impact of these factors can affect disease severity (Garrett et al., 2006, 2014). For weeds, which are less well-studied (Juroszek and Von Tiedemann, 2013), drivers include accelerated $C_{3}$ weed invasiveness and competition under higher atmospheric $\left[\mathrm{CO}_{2}\right]$ (Ziska, 2016), and increased incidence of weed resistance to herbicides (Peters et al., 2014; Ramesh et al., 2017).

Needs for research and action to address knowledge gaps concerning pests and climate change in cereal systems include obtaining additional long-term records of pest abundance or pest injury and coupling these with historical climate records, incorporating pests and natural enemies into niche overlap and 
phenological models, and focusing on mechanisms that employ complementary, comprehensive approaches for understanding the aggregate impact of individual pest, weed, and disease species on future crop productivity (Eigenbrode and Macfadyen, 2017). Although the importance of incorporating plant protection into whole system management is evident, achieving increased integration remains a significant challenge. Often agronomic goals take priority, with pest management issues considered as an afterthought. Agronomic practices such as alternative tillage or more diverse rotational or nutrient management schemes are anticipated to influence pests, weeds, and disease risks. Monitoring insect community responses to various adaptive cropping practices should be studied at experimental field scale in order to avoid unintended consequences and to understand and capitalize on the most effective opportunities to improve pest, weed, and disease management.

\section{Greenhouse Gases: Monitoring and Approaches to Mitigation}

Along with the needs for adaptation to changing climates, it will be important to minimize the negative impacts of agriculture on the climate system. The agricultural sector produces slightly $<10 \%$ of $\mathrm{GHG}$ emissions ( $\mathrm{CO}_{2}$ eq.) in the USA (Snyder et al., 2009) and about $11 \%$ worldwide (FAO, 2014). Approximately $65 \%$ of this total in $\mathrm{CO}_{2}$ eq. is $\mathrm{N}_{2} \mathrm{O}$ emissions from agricultural soils (FAO, 2014); on a per gram basis $\mathrm{N}_{2} \mathrm{O}$ has a Global Warming Potential that is 310 times greater than $\mathrm{CO}_{2}$ (United Nations Framework Convention on Climate Change). Poorly performing agricultural practices contribute to increased GHG emissions associated with deforestation and grassland land use conversion. The magnitude of $\mathrm{N}_{2} \mathrm{O}$ soil emissions, and related emissions from agricultural nitrate runoff in surface waters (e.g., Turner et al., 2015) presents opportunities for innovative agricultural practices (e.g., fertilizers with nitrification inhibitors and precision application of fertilizers) to reduce GHG emissions and benefit producers in the short term. Although the mitigation of agricultural GHG emissions generally does not provide a monetized return to farmers and is not currently encouraged by direct public policy incentives or regulations (Brown et al., 2017); effective adaptation practices could achieve "win-win" benefits in which cropping system profitability is increased through more efficient use of applied nitrogen, resulting in both improved farm productivity and reduced $\mathrm{N}_{2} \mathrm{O}$ emissions (Millar et al., 2010). Roughly $1 \%$ of the nitrogen applied results in $\mathrm{N}_{2} \mathrm{O}$ production, but emissions are variable, influenced by climate, soil organic carbon (SOC), soil texture, soil drainage, soil $\mathrm{pH}$, crop management practices, soil nutrient conditions, and soil $\mathrm{O}_{2}$ status (IFA/FAO, 2001; McSwiney and Robertson, 2005; Del Grosso et al., 2010; Lehuger et al., 2011; Chi et al., 2016, 2017; Waldo et al., 2016).

Improved monitoring of GHG emissions under different cereal production and nutrient management practices is needed for ascertaining the effects of various cropping strategies on GHG emissions and to identify how these emissions could be minimized (e.g., Chirinda et al., 2010; Liebig et al., 2010; Millar et al., 2010; Dendooven et al., 2012; Kostyanovsky et al.,
2017). Increased technical accuracy and more extensive field monitoring of these emissions can be combined with modeling to improve the evidence-base for public policy decisions that affect agricultural productivity and sustainability (Moore et al., 2014; Officer et al., 2015).

Needs are evident for increased GHG monitoring as a component of efforts to improve cereal system resilience to climate change. Data are lacking, particularly fine temporal and spatial scale flux data, on GHG emissions from production systems. This situation should be improved through development of better, less expensive sensors. Accompanying this are needs to understand soil microbial processes and the effects of environmental conditions on their emissions. Precision fertilization practices in large mechanized farming systems and, where appropriate, in small-holder systems, can increase returns to farmers by more efficiently using fertilizer; and also contribute to reduced emissions, thus resulting in so-called win-win scenarios.

\section{Social and Economic Dimensions}

This $\mathrm{G} \times \mathrm{E} \times \mathrm{M} \times \mathrm{S}$ framework (CGIAR, 2012; Figure 1) incorporates the understanding that agricultural systems are social-ecological systems. Adaptation to climate change depends upon technological capabilities, market economic costs and returns of adopting new production practices, and the sociological factors and public policies that govern producer behavior. For example, vulnerability to drought in wheat producing regions varies not only with projected impacts of drought on production, but also with the levels and types of inputs, crop residue retention practice, and other agricultural investments that are made to impart resilience (Challinor et al., 2010; Simelton et al., 2012; Fraser et al., 2013). In addition, actions taken by farmers are influenced by perceptions of climate and climate change patterns, which can differ from measured trends (Kibue et al., 2016) and by other factors (e.g., cultural and individual attitudes) that influence openness to change versus inclination to maintain traditions (e.g., Kok et al., 2009).

In many parts of the world, particularly in north temperate regions, farmers have often been reluctant to accept the validity of climate change, and this perspective reduces their likelihood of adopting new practices (Arbuckle et al., 2013; Jorgensen and Termansen, 2016). Their perceptions of risk, which are essential to motivate adoption (Nigg and Mileti, 2002) can significantly vary, and are influenced by farmers' levels of indebtedness, awareness of alternative practices, age, and other attributes. Farmers' willingness to extend and diversify their crop rotation strategies can also be significantly affected by public and private crop insurance policies that encourage and cover the adoption of new crops and inter-cropping acreages. Thus, integrated research responses to climate change in agriculture should strive to understand these sociological forces and incorporate them into transdisciplinary assessment and strategy recommendation efforts (Maaz T. et al., 2017).

The socio-economic challenges facing small-holder farmers in developing nations are significantly shaped by the constraints and opportunities associated with farming on small parcels of 
land, fragmented landscapes, and limited access to water, inputs and productivity technologies. It must also be recognized that women led small-holder households are a significant segment of the developing world's farming sector; and are often subject to gender discrimination and lack of support from agricultural public institutions and private sector supply chains (Chan, 2010; Doss, 2017). These challenges are compounded by the limited health and education infrastructures and services that are characteristic of poor, rural small-holder communities (Lowder et al., 2016). Small-holders often have more vulnerability to warming environments, particularly in tropical and sub-tropical areas where cereal crops are already cultivated under conditions that are close to their temperature tolerance thresholds (Hossain et al., 2016). This vulnerability is exacerbated by extreme weather events (e.g., droughts, flooding, hurricanes, etc.) that can overwhelm small-holder household resources and the capacities of domestic and international social and public support and disaster recovery institutions and organizations (Hallegatte et al., 2016; Adiku et al., 2017).

Adaptation solutions must be relevant to the local conditions facing the farmer. For example, the "Push-Pull" farming system in East Africa is proving to be a promising integrated crop and livestock strategy for small-holders (Pickett et al., 2014). This practice is suited for the scale of their farm operations and employs traditional elements including intercropping of maize and a fodder to maximize benefits to farmers through suppression of weeds and cereal stem borer pests, providing nitrogen fixation and forage for cattle. This farming practice shows great promise to improve small-holders' total farm productivity and revenues, and reduce their exposure to risks. Whether and how the principles working in east African pushpull systems can be adopted for larger scale systems remains to be examined.

Regardless of a farm's scale, the socioeconomic environment of private sector supply chains and market access, public taxation and regulation policies, agricultural research and extension outreach efforts, and other factors will establish the context within which each farmer operates. Identification of "actionable" agricultural adaptation strategies will require an assessment of both agronomic and socioeconomic forces to determine which practices and technologies would be most effective for farmers in specific circumstances and locations. Development of cfBPM's should include local farmer engagement in the planning and conduct of field research trials that leverage farmer knowledge and experience. Inclusive producer involvement can help identify implementation issues that must be resolved in order to encourage farmers' adoption of innovative practices (Sayre and Govaerts, 2011; Hellin et al., 2014). For example, farming system groups or Communities of Practice, comprised of farmers who work with agricultural industry, ensure that research better serves the needs of farmers in Western Australia (Anil et al., 2015). In the iPNW, proactive farming organizations like Shepherds Grain (https:// www.shepherdsgrain.com) and the Pacific Northwest Direct Seed Association (http://www.directseed.org) help inform and research directions to promote sustainable production in the region.
Decision support tools based on agrometeorological models have been developed or are in development for various semiarid regions to serve large-scale mechanized agriculture or smallholder systems (Sadras et al., 2003; Hochman et al., 2009; McCown et al., 2009; Chen, 2017; Prokopy et al., 2017; http:// climateengine.org, https://www.agbizlogic.com). The increasing accessibility of data, continuing innovation, and improvement of user interfaces, and improvement of climate models is certain to accelerate development and deployment of these tools into the future. There is a great need to support the community of private and public entities working to deliver and improve these tools. Success requires appropriately downscaled climate models, coupled with next generation, regionally relevant cropping system models, presented through interfaces that based on economic and social contexts of their intended user populations (Kibue et al., 2016; Marshall et al., 2016; Nguyen et al., 2016; Panda, 2016).

\section{Ecosystem Services Issues: Landscape Scale and Watershed Management for Sustainability}

Most efforts to improve the productivity, resilience and sustainability of cereal cropping systems primarily focus on practices that impact farm-level yields and their economic viability across a range of operational scales and degrees of technological mechanization (Robertson and Swinton, 2005; Lobell et al., 2009). However, the quality and quantity of agricultural products and their associated financial returns to farmers are not the only outcomes of significance to humanity. The additional challenges of coping with the disruptive forces of climate change and minimizing environmental degradation require that society's strategies for agricultural innovation and development must also address the long-term impacts of farming practices on local and regional ecosystem services (Elbehri et al., 2017).

When impacts of individual on-farm practices are aggregated at a landscape scale to encompass local watershed and regional river basin geographies, the cumulative benefits, and costs of "ecosystem services" can begin to be recognized and valued (Daily, 1997). Ecosystem services are dynamic and complex natural processes that significantly determine water quality, surface water flows, groundwater replenishment, soil formation, soil fertility, and erosion control, habitats for pollinators, pests and pest predator biodiversity, and other environmental conditions (Daily, 1997, 1999; Kremen, 2005; Palmer et al., 2005). Identifying and measuring how agricultural practices impact ecosystem services is challenging because farm operations tend to generate "non-point source" changes to the environment that are often subtle and only discernable over longer time frames than that of seasonal crop harvests and annual returns on investment (Pradhan et al., 2015).

Ecosystem services have an immediate impact locally, by effecting production performance on the individual farm. These services also propagate across landscapes and geographies beyond the "farm gate" (Schellhorn et al., 2008). The beneficial effects of ecosystem services at the farm level, in terms of 
improved soil structure and organic matter, and moisture retention can be recognized and valued for their contributions to building and conserving healthy soils (Lal, 2014). These outcomes enhance the future productivity of the land, one of the fundamental "natural capital" assets of farmers (Pearce and Turner, 1990; Voora and Venema, 2008). The economic returns on farmer investments and practices that promote and contribute to local ecosystem services may be realized over longer periods of time (e.g., from several years to the next generation). Farmers, especially those that own their land, can privately capture some of these benefits in terms of reduced expenses for agrochemical inputs, increased water use efficiencies, biological pest control, and other operational cost savings. They may also benefit from future appreciation of land values due to improved soil tilth and fertility.

Determining the value of agriculture's impact on ecosystem services beyond farm property boundaries is challenging because cumulative "downstream" benefits or adverse effects are determined by combined effects of decisions made by many farmers concerning their cropping system practices (Herrero et al., 2013; Lindborg et al., 2017). These impacts can result in positive outcomes such as cleaner and more abundant fresh water supplies, biological nitrogen fixation nutrient inputs, or improved biodiversity habitats (Dale and Polasky, 2007; Scherr and McNeely, 2008; Power, 2010). They can also result in negative outcomes such as nitrate and phosphorus water pollution or sedimentation of waterways, all accumulating and accruing in the public domain (Rabotyagov et al., 2014; Garnache et al., 2015).

It is difficult and costly to monitor, measure and quantify the extended impacts of ecosystem services on other private parties; economic sectors (e.g., fisheries); and the broader public (e.g., "public health, goods and services"; Jacobs et al., 2016). Accurately attributing water quality conditions to local and regional agricultural practices is challenging. An example of such difficulties can be seen in the USDA's multi-year Conservation Effects Assessment Project (CEAP) that studied several watersheds for water quality impacts of minimum tillage and cover cropping practices. To date, CEAP's field studies have not yet been able to determine how river basin water quality variations can be attributed to specific conservation farming practices within the studied watersheds (Tomer and Locke, 2011). On the other hand, CEAP projects have made significant progress in understanding and demonstrating how agricultural practices could be managed to reduce nitrate and phosphorus water pollution in environmentally sensitive rivers and estuaries (e.g., Mississippi River Basin and Chesapeake Bay; Lund et al., 2011; Osmond et al., 2015). The USDA's continued support of CEAP's field research, farmer education and encouragement of innovation (e.g., the NRCS Environmental Quality Incentives Program assistance to farmer investments in improved practices) is needed to build a better, more accurate knowledge base of how watershed ecosystem services function; and how they could be better protected, managed and valued.

An improved ability to understand and measure regionally scaled ecosystem service impacts is critically needed to inform federal and state regulatory frameworks that guide and govern fertilizer and other agrichemical input application intensities, timing, and cropping system integration. Success in stabilizing and restoring the health of major watersheds and aquatic fisheries will significantly depend on identifying and promoting improved agricultural practices management. An excellent resource that discusses leading efforts and decision support models for assessing ecosystem services valuations and their utility in determining values within a specific regional river basin can be found in a "Case Study of the San Pedro River Watershed, Arizona" published in 2012 by the USGS with cooperation of the Bureau of Land Management (Bagstad et al., 2012).

Semi-arid cereal cultivation significantly benefits from wellfunctioning ecosystem services, and depending upon adopted practices can either positively or adversely impact the continued performance of these natural processes. As an example of these interrelationships, crop residue and ground cover management strategies that reduce soil erosion and weed establishment and return organic nutrients and carbon to the soil are important contributing factors for healthy soil biomes and enhanced water use efficiencies across multiple crop rotations. When individual farmer's best management practices are replicated at landscape scales, local water resources are both qualitatively and quantitatively improved. Similarly, maintenance of riparian buffers, contoured terrain, and natural vegetation habitats can reduce agrichemical runoff to surface waters; and supports biological pest control and pollination services. Leveraging these environmental services are especially significant for non-cereal rotation crops that benefit from insect pollination (e.g., canola). A comprehensive discussion of the opportunities, constraints, and challenges of semi-arid crop production is provided by (Wani et al., 2009).

Inattention to the need to balance these mutually interdependent relationships between cropping systems and their local and extended environment can lead to unintended consequences that impair the productivity of ecosystems that are distant from agricultural areas. An example of the disruptive effect of poorly managed farming practices can be seen in the large hypoxic zone that has formed in the Gulf of Mexico. The excessive levels of nutrients that have leached or runoff from the Upper Midwest agricultural regions are a significant contributing factor to the adverse impacts of the Mississippi River's discharges into the Gulf (García et al., 2016).

\section{Integration}

Agricultural production systems are dynamic, involving interacting technical, social, and ecological factors (Figure 1). A premise of REACCH and TCSACC, which it sponsored, is that correctly addressing the multifaceted challenges to cereal system sustainability requires that these various factors and their interrelationships are considered together, rather than piecemeal. Transdisciplinary efforts that involve scientists and the direct participation of farmers to facilitate field trials are able to benefit from local farmer knowledge and may also catalyze farmers' willingness to collaborate in testing and implementing adaptive, more resilient cropping system practices that are relevant to their local area (Tress et al., 2004). 


\section{GOING FORWARD}

Based on discussions within TCSACC and this perspective paper, progress to achieving more integrated and effective approaches for addressing the challenges of climate change in semi-arid systems will be accelerated by improved interdisciplinary and inter-sectoral integration that can address production at a comprehensive systems level. This is necessary to remediate the typical "siloed" efforts within individual disciplines that can fail to generate actionable knowledge that is urgently needed to improve agriculture systems.

\section{Establish Coordinated, Large-Scale, Transdisciplinary Efforts}

There is a growing body of literature concerned with interdisciplinarity and transdisciplinarity (e.g., Frodeman et al., 2017), but the challenges pertaining to comprehensively addressing large scale production system sustainability are unique (Morton et al., 2015). Participants in REACCH and TCSACC were committed to this view and to identifying the needed linkages across disciplines and sectors. Successfully responding to these challenges will require resources. The term "transdisciplinary" as used here refers to integration across sectors, including scientists and other stakeholders. There is a need for more projects structured like REACCH to support this type of integration across disciplines, geographies, and temporal scales; and to complement such research with outreach and education components.

The REACCH project facilitated a cross-fertilization of ideas and integrated research approaches and results produced by diverse disciplinary teams. Although the REACCH project has concluded, further development and application of multidisciplinary "platforms" will continue in the recently established USDA Long Term Agroecological Research network (LTAR). LTAR is comprised of 18 agricultural research sites managed by selected US land grant universities; and is building collaborative research and data sharing capabilities that address entire production systems and that are supported by field data acquired over lengthy periods of time (http://www.tucson.ars.ag. gov/ltar/). Future success of such large-scale, long term projects will depend upon initiatives that:

\section{Consider $\mathbf{G} \times \mathbf{E} \times \mathbf{M} \times \mathbf{S}$ Interactions}

Genetic improvement and farming systems were historically developed separately. Currently and more so in the future, synergies must be studied so that traits can be developed for compatibility with agronomic systems to maximize potential yield and sustainability. Conceptual, structural, cultural, and statistical and institutional innovation are needed to coordinate the agronomic and genetic efforts. This entails at minimum considering not only the Genotype $\times$ Environment interactions that are requisite for improving crop varieties, but in addition the role of management in achieving the greatest potential on the ground, leading to the $\mathrm{G} \times \mathrm{E} \times \mathrm{M}$ concepts (Hatfield and Walthall, 2015). Discussion at TCSACC embraced the recognized need to extend these efforts to include socioeconomic aspects; deliberately integrating social, scientific, and engineering disciplines to consider the holistic food sector, and to adopt the integrating principles of agroecology (Francis et al., 2008; Hatt et al., 2016) (Figure 1) .

\section{Improve Integration among Knowledge Communities}

Knowledge assets, including archived data relevant to sustainable use of resources, modeling and scenario building, must be accessible to deliver high-quality, relevant information to support decisions about landscape management (Cash et al., 2003), and to facilitate knowledge communication across boundaries (Tàbara and Chabay, 2013). This is related to a participatory research paradigm. Facilitating scientific, evidence-based data that informs and supports decision makers' promulgation of public policies that motivate and assist farmer implementation of Best Management Practices (BMP's) for successfully adapting to climate change challenges. Some advocate for the "upside down" or network focused extension models rather than the traditional model in which scientists provide knowledge to farmers.

\section{Consider Global Context of Production Systems}

In a globalizing world, many production systems are as strongly influenced by extra-regional factors such as global markets and trade, movements of pests and diseases and the quarantines that attempt to mitigate them, as they are by local biophysical and social conditions. The CGIAR's Research Program on "Climate Change and Food Security" (CCAFS) is an important internationally supported effort to develop and promote increased awareness and implementation of "climate smart" agricultural practices throughout the world and to inform decision makers in national and global forums and multi-lateral initiatives. CCAFS has particularly focused on identifying and advocating best practices that could be adopted by small-holder farmers throughout the developing world (Campbell and Dinesh, 2017).

It will also be important to understand how adaptive cropping system strategies can enable the agriculture sector to achieve improved productivity levels with reduced GHG emissions. International efforts to identify, verify, and encourage farming practices that reduce GHG emissions are making gradual progress in gaining inclusion in many countries' "nationally determined contributions" to reduce emissions (i.e., UNFCCC: COP21 Paris Agreement; Richards et al., 2015). In addition, a related initiative by the French Ministry of Agriculture and civil society NGO's seeks to promote farming practices that sequester organic carbon in soils: www.4p1000.org (Minasny et al., 2017), effectively drawing down atmospheric $\mathrm{CO}_{2}$ levels while simultaneously improving soil health at landscape scales (FAO, 2017).

\section{Develop More Inclusive Cropping System Models}

With the leadership of AGMIP, cropping system model development seeks to involve more disciplines to inform models that incorporate more of the suite of factors that influence cropping system performance. Gaps remain, notably the need to incorporate pests, weeds, diseases, rotational effects, soil and nutrient variables, and episodic abiotic stresses into these models. 
Pursuit of this goal supports large projects and the community of large projects seeking to conduct research that integrates these multiple factors. Crop models can support systems thinking and provide system modeling and linked models that can be used by scientists and by policy makers. For example, cropping system models can be components in regional hydrological modeling approaches that include cropping system models, such as BioEarth at Washington State University (http://bioearth.wsu. edu).

\section{Enable Comprehensive Data Management and Data Sharing}

Large, integrated projects require systems to store, access, manipulate and visualize data. Global modeling efforts, like AGMIP, depend upon agronomic and other data from multiple systems that can be accessed for model improvement and system comparisons. The existing systems for achieving this must be maintained. Comparative and collaborative efforts for innovation in the rapidly changing field of data management for large projects and regional collaborations will be essential.

\section{Include Landscape and Ecosystem Services Perspectives}

Cropping systems exist within landscapes that include diverse other land uses. Pests and the natural enemies potentially move among land uses influencing if not ensuring the sustained performance of the production elements. Hydrological resources are also shared within these landscapes. Thus, successful agriculture requires attention to sustaining these services while minimizing the disservices that can occur at the landscape level from inappropriate, intensive production technology (Schellhorn et al., 2008; Power, 2010; Veres et al., 2013).

\section{Establish and Support Existing Global Networks}

TCSACC participants endorsed the importance of nurturing existing networks of scientists working to help cereal systems in semi-arid regions transition in response to changing climates and other global and local challenges. Momentum from the conference has contributed to two activities: (1) The International Wheat Initiative's Expert Working Group on Wheat Agronomy (Agronomy EWG), which is premised on the requirement for interdisciplinary approaches to improving cereal-based cropping systems, was established in 2016 (http:// www.wheatinitiative.org/activities/expert-working-groups/ wheat-agronomy); (2) in support of this, a "Wheat Initiative Agronomists Community" (WIAC) within the Agronomy Society of America has been formed to facilitate a global community of researchers dedicated to reducing yield gaps by considering these systems holistically (https://www.agronomy. org/membership/communities/wheat-initiative-agronomists-

\section{REFERENCES}

Abatzoglou, J. T., Rupp, D. E., and Mote, P. W. (2014). Seasonal climate variability and change in the Pacific Northwest of the United States. J. Clim. 27, 2125-2142. doi: 10.1175/JCLI-D-1300218.1 community). The WIAC is undertaking an international inventory of research underway to address wheat system agronomy with a longer term aim to identify research priorities within and among countries and regions.

\section{CONCLUSION}

TCSACC, the Agronomy EWG, and other gatherings and initiatives have recognized the importance of coordinated, collaborative efforts to support adaptation of vitally important cereal production systems of the world, especially those located in the already vulnerable semi-arid regions that are critical for food security. As the TCSACC title indicates, many of these systems must transition to new agronomic practices to achieve sustainability. Inherently, this entails efforts that must consider these systems in their entirety from crop genetics; to agronomic practices that conserve water and soil resources; and innovative responses to changing pest, disease and weed pressures. These efforts will require better tools and models to more clearly anticipate specific climate-change related challenges in the near, middle, and long term. All of this must occur through partnerships that consider the social and economic constraints and opportunities available at the local, regional, continental, and global scale. The need is acute. Going forward, resource allocation to research and policy to support successful transitions for semi-arid cereal systems should be guided by this inclusive perspective. One successful model for doing so is provided by the REACCH project in which a large team of scientists and educators is funded and charged with achieving the requisite transdisciplinary integration at regional and, ideally decadal scales. We urge the adoption of this and similar models without delay.

\section{AUTHOR CONTRIBUTIONS}

SE: convened the TCSACC conference that provides the basis and impetus for this article, organized the author team and writing process, conducted research, and composed and edited the text; WB: participated in the TCSACC conference and author team meetings, conducted research, and composed and edited the text; DH: participated in the TCSACC conference and author team meetings, conducted research, and composed and edited the text.

\section{ACKNOWLEDGMENTS}

This is a publication of the Idaho Agricultural Experiment Station. Its preparation was supported by Award \#2011680020-30191 from the USDA National Institute of Food and Agriculture.

Adiku, S. G. K., Debrah-Afanyede, E., Greatrex, H., Zougmore, R., and Maccarthy, D. S. (2017). WeatherIndex Based Crop Insurance as a Social Adaptation to Climate Change and Variability in the Upper West Region of Ghana: Developing a Participatory Approach, CCAFS Working Paper no. 189. Copenhagen: CGIAR Research Program on Climate Change, Agriculture and Food Security (CCAFS). Available online at: https://ccafs.cgiar.org 
Anderson, W., Hamza, M., Sharma, D., D'antuono, M., Hoyle, F., Hill, N., et al. (2005). The role of management in yield improvement of the wheat crop-a review with special emphasis on Western Australia. Aust. J. Agric. Res. 56, 1137-1149. doi: 10.1071/AR 05077

Anderson, W., Johansen, C., and Siddique, K. H. M. (2016). Addressing the yield gap in rainfed crops: a review. Agron. Sustain. Dev. 36:18. doi: 10.1007/s13593-015-0341-y

Anil, B., Tonts, M., and Siddique, K. H. M. (2015). Strengthening the performance of farming system groups: perspectives from a Communities of Practice framework application. Int. J. Sustain. Dev. World Ecol. 22, 219-230. doi: 10.1080/13504509.2014.1003153

Antle, J. M., Mu, J. E., Zhang, H., Capalbo, S. M., Diebel, P. L., Eigenbrode, S. D., et al. (2017). Design and ue of representative agricultural pathways for integrated assessment of climate change in U.S. Pacific Northwest cereal-based systems. Front. Ecol. Evol. 5:99. doi: 10.3389/fevo.2017.00099

Arbuckle, J., Morton, L. W., and Hobbs, J. (2013). Trust, beliefs, and perceived risk as determinants of farmer support for adaptive and mitigative responses to climate change. Environ. Behav. 47, 205-234. doi: 10.1177/0013916513503832

Asseng, S., Ewert, F., Martre, P., Rötter, R. P., Lobell, D. B., Cammarano, D., et al. (2014). Rising temperatures reduce global wheat production. Nat. Clim. Chang. 5, 143-147. doi: 10.1038/nclimate2470

Asseng, S., Ewert, F., Rosenzweig, C., Jones, J. W., Hatfield, J. L., Ruane, A. C., et al. (2013). Uncertainty in simulating wheat yields under climate change. Nat. Clim. Chang. 3, 827-832. doi: 10.1038/nclimate1916

Bagstad, K. J., Semmens, D., Winthrop, R., Jaworski, D., and Larson, J. (2012). Ecosystem Services Valuation to Support Decisionmaking on Public Lands-A Case Study of the San Pedro River Watershed, Arizona. Scientific Investigations Report 2012-5251. U.S. Geological Survey.

Bebber, D. P. (2015). Range-expanding pests and pathogens in a warming World. Annu. Rev. Phytopathol. 53, 335-356. doi: 10.1146/annurev-phyto-080614-120207

Bebber, D. P., Ramotowski, M. A. T., and Gurr, S. J. (2013). Crop pests and pathogens move polewards in a warming world. Nat. Clim. Chang. 3, 985-988. doi: $10.1038 /$ nclimate 1990

Brown, T. T., Lee, C. M., Kruger, C. E., Reganold, J. P., and Huggins, D. R. (2017). Comparison of greenhouse gas offset quantification protocols for nitrogen management in dryland wheat cropping systems of the Pacific Northwest. Front. Environ. Sci. 5:72. doi: 10.3389/fenvs.2017.00072

Campbell, B., and Dinesh, D. (eds.) (2017). Special Issue on Climate-Smart Agriculture (CSA). Agriculture for Development no. 30.

Cash, D. W., Clark, W. C., and Alcock, F. (2003). Knowledge systems for sustainable development. Proc. Natl. Acad. Sci. U.S.A. 100, 8086-8091. doi: $10.1073 /$ pnas. 1231332100

CGIAR (2012). "A stripe review of natural resources management research in the CGIAR,” in Natural Resources Management (Rome: CGIAR).

Challinor, A. J., Simelton, E. S., Fraser, E. D. G., Hemming, D., and Collins, M. (2010). Increased crop failure due to climate change: assessing adaptation options using models and socio-economic data for wheat in China. Environ. Res. Lett. 5:034012. doi: 10.1088/1748-9326/5/3/034012

Challinor, A. J., Watson, J., Lobell, D. B., Howden, S. M., Smith, D. R., and Chhetri, N. (2014). A meta-analysis of crop yield under climate change and adaptation. Nat. Clim. Chang. 4, 287-291. doi: 10.1038/nclimate2153

Chan, M.-K. (2010). Improving Opportunities for Women in Small-Holder-Based Supply Chain. Seattle, WA: The Bill \& Melinda Gates Foundation.

Chen, A. (2017). Spatially explicit modelling of agricultural dynamics in semi-arid environments. Ecol. Modell. 363, 31-47. doi: 10.1016/j.ecolmodel.2017.08.025

Chi, J., Maureira, F., Waldo, S., Pressley, S. N., Stöckle, C. O., O’keeffe, P. T., et al. (2017). Carbon and water budgets in multiple wheat-based cropping systems in the Inland Pacific Northwest US: comparison of cropsyst simulations with eddy covariance measurements. Front. Ecol. Evol. 5:50. doi: 10.3389/fevo.2017.00050

Chi, J., Waldo, S., Pressley, S., O'keeffe, P., Huggins, D., Stöckle, C., et al. (2016). Assessing carbon and water dynamics of no-till and conventional tillage cropping systems in the inland Pacific Northwest US using the eddy covariance method. Agric. For. Meteorol. 218-219, 37-49. doi: 10.1016/j.agrformet.2015.11.019

Chirinda, N., Olesen, J. E., Porter, J. R., and Schjonning, P. (2010). Soil properties, crop production and greenhouse gas emissions from organic and inorganic fertilizer-based arable cropping systems. Agric. Ecosyst. Environ. 139, 584-594. doi: 10.1016/j.agee.2010.10.001

Coakley, S. M., Scherm, H., and Chakraborty, S. (1999). Climate change and plant disease management. Annu. Rev. Phytopathol. 37, 399-426. doi: 10.1146/annurev.phyto.37.1.399

Collins, M., Knutti, R., Arblaster, J., Dufresne, J.-L., Fichefet, T., Friedlingstein, P., et al. (2013). "Long-term climate change: projections, commitments and irreversibility," in Climate Change 2013: The Physical Science Basis. Contribution of Working Group I to the Fifth Assessment Report of the Intergovernmental Panel on Climate Change, eds T. F. Stocker, D. Qin, G.-K. Plattner, M. Tignor, S. K. Allen, J. Boschung, A. Nauels, Y. Xia, V. Bex, and P. M. Midgley (Cambridge, UK; New York, NY: Cambridge University Press), 1029-1136.

Currie, Y., Moch, J., Underwood, J., Kharabsheh, H., Quesenberry, A., Miyagi, R., et al. (2014). Transient heat stress compromises the resistance of wheat (Poales: Poaceae) weedlings to Hessian fly (Diptera: Cecidomyiidae) infestation. J. Econ. Entomol. 107, 389-395. doi: 10.1603/EC13261

Daily, G. C. (ed.) (1997). Nature’s Services. Washington, D.C.: Island Press.

Daily, G. C. (1999). Developing a scientific basis for managing earth's life support systems. Conserv. Ecol. 3:14.

Dale, V., and Polasky, S. (2007). Measures of the effects of agricultural practices on ecosystem services. Ecol. Econ. 64, 286-296. doi: 10.1016/j.ecolecon.2007.05.009

Davis, T. S., Bosque-Pérez, N. A., Foote, N. E., Magney, T., and Eigenbrode, S. D. (2015a). Environmentally dependent host-pathogen and vector-pathogen interactions in the Barley yellow dwarf virus pathosystem. J. Appl. Ecol. 52, 1392-1401. doi: 10.1111/1365-2664.12484

Davis, T. S., Bosque-Pérez, N. A., Popova, I., and Eigenbrode, S. D. (2015b). Evidence for additive effects of virus infection and water availability on phytohormone induction in a staple crop. Front. Ecol. Evol. 3:114. doi: $10.3389 /$ fevo.2015.00114

Davis, T. S., Wu, Y., and Eigenbrode, S. D. (2017). The effects of Bean leafroll virus on life history traits and host selection behavior of specialized pea aphid (Acyrthosiphon pisum, Hemiptera: Aphididae) genotypes. Environ. Entomol. 46, 68-74. doi: 10.1093/ee/nvw150

Del Grosso, S. J., Ogle, S. M., Parton, W. J., and Breidt, F. J. (2010). Estimating uncertainty in $\mathrm{N}_{2} \mathrm{O}$ emissions from US cropland soils. Global Biogeochem. Cycles, 24:GB1009. doi: 10.1029/2009GB003544

Dendooven, L., Gutiérrez-Oliva, V. F., Patiño-Zúñiga, L., Ramírez-Villanueva, D. A., Verhulst, N., Luna-Guido, M., et al. (2012). Greenhouse gas emissions under conservation agriculture compared to traditional cultivation of maize in the central highlands of Mexico. Sci. Tot. Environ. 431, 237-244. doi: 10.1016/j.scitotenv.2012.05.029

Dent, J. B., and Blackie, M. J. (1979). Systems Simulation in Agriculture. London: Applied Science Publishers.

Doblas-Reyes, F. J., García-Serrano, J., Lienert, F., Biescas, A. P., and Rodrigues, L. R. L. (2013). Seasonal climate predictability and forecasting: status and prospects. Wiley Interdisc. Rev. 4, 245-268. doi: 10.1002/wcc.217

Doss, C. (2017). Women and agricultural productivity: reframing the Issues. Dev. Policy Rev. 36, 35-50. doi: 10.1111/dpr.12243

Duncan, W. G., Loomis, R. S., Williams, W. A., and Hanau, R. (1967). A model for simulating photosynthesis in plant communities. Hilgardia 38, 181-205. doi: 10.3733/hilg.v38n04p181

Dyer, L. A., Richards, L. A., Short, S. A., and Dodson, C. D. (2013). Effects of $\mathrm{CO}_{2}$ and temperature on tritrophic interactions. PLoS ONE 8:e62528. doi: 10.1371/journal.pone.0062528

Eigenbrode, S. D., Davis, T. S., and Crowder, D. W. (2015). "Climate change and biological control in agricultural systems: principles and examples from North America," in Climate Change and Insect Pests, eds C. Bjorkman and P. Niemela (Oxon: CABI), 119-135.

Eigenbrode, S. D., and Macfadyen, S. (2017). "The impact of climate change on wheat insect pests: current knowledge and future trends," in Achieving Sustainable Cultivation of Wheat, Volume 1: Breeding, Quality Traits, Pests and Diseases, ed P. Langridge (Cambridge, UK: Burleigh Dodds Science Publishing), 545-567.

Eigenbrode, S. D., Martin, T., Wright Morton, L., Colletti, J., Goodwin, P., Gustafson, R., et al. (2017). Leading Large Transdisciplinary Projects Addressing Social-Ecological Systems: A Primer for Project Directors. Available online at: https://nifa.usda.gov/leading-transdisciplinary-projects 
Eigenbrode, S. D., Morton, L. W., and Martin, T. A. (2014). Big interdisciplinarity to address climate change and agriculture: lessons from three USDA Coordinated Agricultural Projects. J. Soil Water Conserv. 69, 170A-175A. doi: 10.2489/jswc.69.6.170A

Elbehri, A., Challinor, A., Verchot, L., Angelsen, A., Hess, T., Ouled Belgacem, A., et al. (2017). FAO-IPCC Expert Meeting on Climate Change, Land Use and Food Security: Final Meeting Report. Rome: FAO and IPCC.

FAO (2011). Organic Agriculture and Climate Change Mitigation: A Report of the Round Table on Organic Agriculture and Climate Change. Rome: Food and Agriculture Organization of the United Nations (FAO) Natural Resources Management and Environment Department.

FAO (2014). FAOSTAT: Emissions-land Use. Available online at: http://faostat3. fao.org/faostat-gateway/go/to/download/G2/*/E (Accessed January 15, 2017).

FAO (2017). Soil Organic Carbon: the Hidden Potential. Rome: Food and Agriculture Organization of the United Nations.

Flathers, E., Kenyon, J., and Gessler, P. E. (2017). A service-based framework for the OAIS model for earth science data management. Earth Sci. Inform. 10, 383-393. doi: 10.1007/s12145-017-0297-3

Foote, N. E., Davis, T. S., Crowder, D. W., Bosque-Pérez, N. A., and Eigenbrode, S. D. (2017). Plant water stress affects interactions between an invasive and a naturalized aphid species on cereal crops. Environ. Entomol. 46, 609-616. doi: $10.1093 / \mathrm{ee} / \mathrm{nvx} 071$

Francis, C. A., Lieblein, G., Breland, T. A., Salomonsson, L., Geber, U., Sriskandarajah, N., et al. (2008). Transdisciplinary research for a sustainable agriculture and food sector. Agron. J. 100, 771-776. doi: 10.2134/agronj2007.0073

Fraser, E. D. G., Simelton, E., Termansen, M., Gosling, S. N., and South, A. (2013). "Vulnerability hotspots": integrating socio-economic and hydrological models to identify where cereal production may decline in the future due to climate change induced drought. Agric. For. Meteorol. 170, 195-205. doi: 10.1016/j.agrformet.2012.04.008

Frodeman, R., Klein, J. T., and Pacheco, R. (2017). The Oxford Handbook of Interdisciplinarity, 2nd Edn. Oxford: Oxford University Press.

Fuhrer, J. (2003). Agroecosystern responses to combinations of elevated $\mathrm{CO}_{2}$, ozone, and global climate change. Agric. Ecosyst. Environ. 97, 1-20.doi: 10.1016/S0167-8809(03)00125-7

García, A. M., Alexander, R. B., Arnold, J. G., Norfleet, L., White, M. J., Robertson, D. M., et al. (2016). Regional effects of agricultural conservation practices on nutrient transport in the upper Mississippi River Basin. Environ. Sci. Technol. 50, 6991-7000. doi: 10.1021/acs.est.5b03543

Garnache, C., Swinton, S. M., Herriges, J. A., Lupia, F., and Stevenson, R. J. (2015). "Solving the phosphorus pollution puzzle: synthesis and directions for future research," in Invited Paper for 2016 Allied Social Science Associations Meeting (San Franscisco, CA).

Garrett, K. A., Dendy, S. P., Frank, E. E., Rouse, M. N., and Travers, S. E. (2006). Climate change effects on plant disease: genomes to ecosystems. Annu. Rev. Phytopathol. 44, 489-509. doi: 10.1146/annurev.phyto.44.070505.143420

Garrett, K. A., Thomas-Sharma, S., Forbes, G. A., and Nopsa, J. H. (2014). "Climate change and plant pathogen invasions," in Invasive Species and Global Climate Change, Vol. 4, eds L. H. Ziska and J. S. Dukes (Wallingford: CABI), 22-44.

Gillespie, D. R., Olfert, O., and Cock, J. W. (2013). "Climate change and biological control in Canada," in Biological Control Programmes in Canada, 2001-2012, eds P. G. Mason and D. R. Gillespie (Oxfordshire: CABI), 12-22.

Hallegatte, S., Bangalore, M., Bonzanigo, L., Fay, M., Kane, T., Narloch, U., et al. (2016). Shock Waves: Managing the Impacts of Climate Change on Poverty. Washington, DC: World Bank.

Hatfield, J. L., Sauer, T. J., and Prueger, J. H. (2001). Managing soils to achieve greater water use efficiency. Agron. J. 93, 271-280. doi: 10.2134/agronj2001.932271x

Hatfield, J. L., and Walthall, C. L. (2015). Meeting global food needs: realizing the potential via genetics $\times$ environment $\times$ management interactions. Agron. J. 107, 1215-1226. doi: 10.2134/agronj15.0076

Hatt, S., Artru, S., Brédart, D., Lassois, L., Francis, F., Haubruge, E., et al. (2016). Towards sustainable food systems: the concept of agroecology and how it questions current research practices. A review. Biotechnol. Agron. Soc. Environ. 20, 215-224. Available online at: http://popups.ulg.ac.be/1780-4507/index.php? id $=12997$
Heady, E. O. (1957). An econometric investigation of agricultural production functions. Econometrica 25, 249-268. doi: 10.2307/1910253

Hellin, T., Beuchelt, T., Camacho, C., Badstue, L., Govaerts, B., Donnet, L., et al. (2014). An Innovation Systems Approach to Enhanced Farmer Adoption of Climate-Ready Germplasm and Agronomic Practices. CAPRi Working Paper No. 116. Washington, DC. International Food Policy Research Institute.

Herrero, J., Millares, A., Aguilar, C., Bonet, F. J., and Polo, M. J. (2013). "Assimilation of remotely sensed data into hydrologic modeling for ecosystem services assessment," in Earth Observation of Ecosystem Services, eds D. AlcarazSegura, C. M. Di Bella, and J. V. Straschnoy (Boca Raton, FL: CRC Press), 261-282.

Hijmans, R. J., Cameron, S. E., Parra, J. L., Jones, P. G., and Jarvis, A. (2005). Very high resolution interpolated climate surfaces for global land areas. Int J. Climatol. 25, 1965-1978. doi: 10.1002/joc.1276

Hochman, Z., Van Rees, H., Carberry, P. S., Hunt, J. R., Mccown, R. L., Gartmann, A., et al. (2009). Re-inventing model-based decision support with Australian dryland farmers. 4. Yield Prophet (R) helps farmers monitor and manage crops in a variable climate. Crop Pasture Sci. 60, 1057-1070. doi: 10.1071/CP 09020

Holzworth, D. P., Huth, N. I., Devoil, P. G., Zurcher, E. J., Herrmann, N. I., Mclean, G., et al. (2014). APSIM - Evolution towards a new generation of agricultural systems simulation. Environ. Model. Softw. 62, 327-350. doi: 10.1016/j.envsoft.2014.07.009

Hoogenboom, G., Jones, J. W., Wilkens, P. W., Porter, C. H., Boote, K. J., Hunt, L. A., et al. (2012). Decision Support System for Agrotechnology Transfer (DSSAT) Version 4.5 [CD-ROM]. Honolulu, HI: University of Hawaii.

Hossain, K., Quaik, S., Ismail, N., Rafatullah, M., Ali, I., Hatta, Z. A., et al. (2016). Climate change-perceived impacts on agriculture, vulnerability and response strategies for improving adaptation practice in developing countries (South Asian Region). Int. J. Agric. Res. 11, 1-12. doi: 10.3923/ijar.2016.1.12

Howden, S. M., Soussana, J. F., Tubiello, F. N., Chhetri, N., Dunlop, M., and Meinke, H. (2007). Adapting agriculture to climate change. Proc. Natl. Acad. Sci. U.S.A. 104, 19691-19696. doi: 10.1073/pnas.0701890104

IFA/FAO (2001). Global Estimates of Gaseous Emissions of $\mathrm{NH}_{3}, \mathrm{NO}$, and $\mathrm{N}_{2} \mathrm{O}$ from Agricultural Land. Rome: International Fertilizer Association (IFA) and the Food and Agriculture Organization of the United Nations (FAO).

IPCC (2014). "Climate change 2014: synthesis report," in Contribution of Working Groups I, II and III to the Fifth Assessment Report of the Intergovernmental Panel on Climate Change, eds Core Writing Team, R. K. Pachauri and L. A. Meyer (Geneva: IPCC).

Jacobs, S., Dendoncker, N., Martín-López, B., Barton, D., Gomez-Baggethun, E., Boeraeve, F., et al. (2016). A new valuation school: integrating diverse values of nature in resource and land use decisions. Ecosyst. Serv. 22, 213-220. doi: 10.1016/j.ecoser.2016.11.007

Jawson, M. D., Shafer, S. R., Franzluebbers, A. J., Parkin, T. B., and Follett, R. F. (2005). GRACEnet: greenhouse gas reduction through agricultural carbon enhancement network. Soil Tillage Res. 83, 167-172. doi: 10.1016/j.still.2005.02.015

Jones, J. W., Antle, J. M., Basso, B., Boote, K. J., Conant, R. T., Foster, I., et al. (2016). Brief history of agricultural systems modeling. Agric. Syst. 155, 1-15. doi: 10.1016/j.agsy.2016.05.014

Jorgensen, S. L., and Termansen, M. (2016). Linking climate change perceptions to adaptation and mitigation action. Clim. Change 138, 283-296. doi: $10.1007 / \mathrm{s} 10584-016-1718-\mathrm{x}$

Juroszek, P., and Von Tiedemann, A. (2013). Plant pathogens, insect pests and weeds in a changing global climate: a review of approaches, challenges, research gaps, key studies and concepts. J. Agric. Sci. 151, 163-188. doi: $10.1017 /$ S0021859612000500

Juroszek, P., and Von Tiedemann, A. (2015). Linking plant disease models to climate change scenarios to project future risks of crop diseases: a review. J. Plant Dis. Protect. 122, 3-15. doi: 10.1007/BF033 56525

Kalra, N., Chander, S., Pathak, H., Aggarwal, P. K., Gupta, N. C., Sehgal, M., et al. (2007). Impacts of climate change on agriculture. Outlook Agric. 36, 109-118. doi: $10.5367 / 000000007781159903$

Karimi, T., Stöckle, C. O., Higgins, S. S., Nelson, R. L., and Huggins, D. (2017). Projected dryland cropping system shifts in the Pacific Northwest in 
response to climate change. Front. Ecol. Evol. 5:20. doi: 10.3389/fevo.2017. 00020

Kaur, H., Huggins, D. R., Rupp, R. A., Abatzoglou, J. T., Stöckle, C. O., and Reganold, J. P. (2017). Agro-ecological class stability decreases in response to climate change projections for the Pacific Northwest, USA. Front. Ecol. Evol. 5:74. doi: 10.3389/fevo.2017.00074

Kibue, G., Liu, X., Zheng, J., Zhang, X., Pan, G., Li, L., et al. (2016). Farmers' perceptions of climate variability and factors influencing adaptation: evidence from Anhui and Jiangsu, China. Environ. Manage. 57, 976-986. doi: 10.1007/s00267-016-0661-y

Kirkegaard, J., Christen, O., Krupinsky, J., and Layzell, D. (2008). Break crop benefits in temperate wheat production. Field Crops Res. 107, 185-195. doi: 10.1016/j.fcr.2008.02.010

Kirkegaard, J. A., Hunt, J. R., Mcbeath, T. M., Lille, Y., J. M., Moore, A., Verburg, K., et al. (2014). Improving water productivity in the Australian grains industry - a nationally coordinated approach. Crop Pasture Sci. 65, 583-601. doi: 10.1071/CP14019

Kok, H., Papendick, R., and Saxton, K. (2009). STEEP: impact of long-term conservation farming research and education in Pacific Northwest wheatland. J. Soil Water Conserv. 64, 253-264. doi: 10.2489/jswc.64.4.253

Kole, C., Muthamilarasan, M., Henry, R., Edwards, D., Sharma, R., Abberton, M., et al. (2015). Application of genomics-assisted breeding for generation of climate resilient crops: progress and prospects. Front. Plant Sci. 6:563. doi: $10.3389 /$ fpls.2015.00563

Kostyanovsky, K., Huggins, D. R., Stöckle, C., Waldo, S. R., and Lamb, B. K. (2017). Developing a flow through chamber system for automated measurements of soil $\mathrm{N}_{2} \mathrm{O}$ and $\mathrm{CO}_{2}$ emissions. Measurement 113, 172-180. doi: 10.1016/j.measurement.2017.05.040

Kremen, C. (2005). Managing ecosystem services: what do we need to know about their ecology? Ecol. Lett. 8, 468-479. doi: 10.1111/j.1461-0248.2005. 00751.x

Kruger, C., and Yorgey, G. (2017). Advances in Dryland Farming in the Inland Pacific Northwest. Pullman, WA: Washington State University Extension EM108.

Kumar, S., Ramilan, T., Ramarao, C. A., Rao, C. S., and Whitbread, A. (2016). Farm level rainwater harvesting across different agro climatic regions of India: assessing performance and its determinants. Agric. Water Manage. 176, 55-66. doi: 10.1016/j.agwat.2016.05.013

Lal, R. (2014). Soil conservation and ecosystem services. International Soil and Water Conservation Research 2, 36-47. doi: 10.1016/S2095-6339(15)30021-6

Lehuger, S., Gabrielle, B., Laville, P., Lamboni, M., Loubet, B., and Cellier, P. (2011). Predicting and mitigating the net greenhouse gas emissions of crop rotations in Western Europe. Agricultural and Forest Meteorology 151, 1654-1671. doi: 10.1016/j.agrformet.2011.07.002

Liebig, M. A., Tanaka, D. L., and Gross, J. R. (2010). Fallow Effects on Soil Carbon and Greenhouse Gas Flux in Central North Dakota. Soil Science Society of America Journal 74, 358-365. doi: 10.2136/sssaj2008.0368

Lindborg, R., Gordon, L. J., Malinga, R., Bengtsson, J., Peterson, G., Bommarco, R., et al. (2017). How spatial scale shapes the generation and management of multiple ecosystem services. Ecosphere 8:e01741. doi: 10.1002/ecs2.1741

Lobell, D., Cassman, K., and Field, C. (2009). Crop yield gaps: their importance, magnitudes and causes. Annu. Rev. Environ. Resour. 34, 179-204. doi: 10.1146/annurev.environ.041008.093740

Lobell, D. B., and Tebaldi, C. (2014). Getting caught with our plants down: the risks of a global crop yield slowdown from climate trends in the next two decades. Environ. Res. Lett. 9:074003. doi: 10.1088/1748-9326/9/7/074003

Lowder, S. K., Skoet, J., and Raney, T. (2016). The number, size, and distribution of farms, small-holder farms, and family farms worldwide. World Dev. 87, 16-29. doi: 10.1016/j.worlddev.2015.10.041

Lund, D., Jay, D., Atwood Bagdon, J. K., Goebel, J., Kevin, I., Kellogg, R. L., et al. (2011). Assessment of the Effects of Conservation Practices on Cultivated Cropland in the Chesapeake Bay Region. USDA-NRCS.

Maaz, T., Wulfhorst, J. D., McCracken, V., Kirkegaard, J., Huggins, D. R., Roth, I., et al. (2017). Economic, policy, and social trends and challenges of introducing oilseed and pulse crops into dryland wheat rotations. Agric. Ecosyst. Environ. 253, 177-194. doi: 10.1016/j.agee.2017.03.018

Maaz, T. M., Schillinger, W. F., Machado, S., Brooks, E., Johnson-Maynard, J. L., Young, L. E., et al. (2017). Impact of climate change adaptation strategies on winter wheat and cropping system performance across precipitation gradients in the Inland Pacific Northwest, USA. Front. Environ. Sci. 5:23. doi: $10.3389 /$ fenvs.2017.00023

Marshall, N. A., Crimp, S., Curnock, M., Greenhill, M., Kuehne, G., Leviston, Z., et al. (2016). Some primary producers are more likely to transform their agricultural practices in response to climate change than others. Agric. Ecosyst. Environ. 222, 38-47. doi: 10.1016/j.agee.2016.02.004

Mayer, A. (2013). Climate change already challenging agriculture. Bioscience 63, 781-787. doi: 10.1525/bio.2013.63.10.2

McCown, R. L., Carberry, P. S., Hochman, Z., Dalgliesh, N. P., and Foale, M. A. (2009). Re-inventing model-based decision support with Australian dryland farmers. 1. Changing intervention concepts during 17 years of action research. Crop Pasture Sci. 60, 1017-1030. doi: 10.1071/CP08455

McSwiney, C. P., and Robertson, G. P. (2005). Nonlinear response of $\mathrm{N}_{2} \mathrm{O}$ flux to incre- mental fertilizer addition in a continuous maize (Zea mays L.) cropping system. Glob. Change Biol. 11, 1712-1719. doi: $10.1111 /$ j.1365-2486.2005.01040.x

Meinke, H., and Stone, R. C. (2005). Seasonal and inter-annual climate forecasting: the new tool for increasing preparedness to climate variability and change in agricultural planning and operations. Clim. Change 70, 221-253. doi: 10.1007/s10584-005-5948-6

Millar, N., Robertson, G. P., Grace, P., Gehl, R., and Hoben, J. P. (2010). Nitrogen fertilizer management for nitrous oxide $\left(\mathrm{N}_{2} \mathrm{O}\right)$ mitigation in intensive corn (Maize) production: an emissions reduction protocol for US Midwest agriculture. Mitig. Adapt. Strategies Glob. Chang. 15, 185-204. doi: 10.1007/s11027-010-9212-7

Minasny, B., Malone, B., Mcbratney, A., Angers, D., Arrouays, D., Chambers, A., et al. (2017). Soil carbon, 4 per mile. Geoderma 292, 59-86. doi: 10.1016/j.geoderma.2017.01.002

Moore, A. D., Eckard, R. J., Thorburn, P. J., Grace, P. R., Wang, E. L., and Chen, D. L. (2014). Mathematical modeling for improved greenhouse gas balances, agroecosystems, and policy development: lessons from the Australian experience. Wiley Interdisc. Rev. 5, 735-752. doi: 10.1002/wcc.304

Morton, L. W., Eigenbrode, S. D., and Martin, T. A. (2015). Architectures of adaptive integration in large collaborative projects. Ecol. Soc. 20, 5. doi: 10.5751/ES-07788-200405

National Agricultural Statistics Service (NASS) (2015). Agricultural Statistics 2015. Washington, DC: United States Government Printing Office.

National Science Foundation (USA) (2015). America's Future: Environmental Research and Education for a Thriving Century. A Report by the NSF Advisory Committee for Environmental Research and Education. Washington, DC: National Science Foundation.

Nguyen, T. P. L., Mula, L., Cortignani, R., Seddaiu, G., Dono, G., Virdis, S. G. P., et al. (2016). Perceptions of present and future climate change impacts on water availability for agricultural systems in the Western Mediterranean region. Water 8:523. doi: 10.3390/w8110523

Nigg, J. M., and Mileti, D. (2002). "Natural hazards and disasters," in Handbook of Environmental Sociology, eds R. E. Dunlap and W. Michelson (Westport, CT: Greenwood Press), 272-294.

Officer, S. J., Phillips, F., Kearney, G., Armstrong, R., Graham, J., and Partington, D. (2015). Response of soil nitrous oxide flux to nitrogen fertiliser application and legume rotation in a semi-arid climate, identified by smoothing spline models. Soil Res. 53, 227-241. doi: 10.1071/SR12049

Osmond, D. L., Hoag, D. L., Luloff, A. E., Meals, D. W., and Neas, K. (2015). Farmers' use of nutrient management: lessons from watershed case studies. J. Environ. Qual. 44, 382-390. doi: 10.2134/jeq2014.02.0091

Palmer, M. A., Bernhardt, E. S., Chornesky, E. A., Collins, S. L., Dobson, A. P., Duke, C. S., et al. (2005). Ecological science and sustainability for the 21st century. Front. Ecol. Environ. 3, 4-11. doi: 10.1890/15409295(2005)003[0004:ESASFT]2.0.CO;2

Pan, W. L., Schillinger, W. F., Young, F. L., Kirby, E. M., Yorgey, G. G., Borrelli, K. A., et al. (2017). Integrating historic agronomic and policy lessons with new technologies to drive farmer decisions for farm and climate: the case of inland Pacific Northwestern U.S. Front. Environ. Sci. 5:76. doi: 10.3389/fenvs.2017.00076

Pan, W. L., Young, F. L., Hulbert, S. C., Huggins, D. R., and Maaz, T. M. (2016). Canola integration into semi-arid wheat cropping systems of the inland Pacific Northwestern USA. Crop Pasture Sci. 67, 253-265. doi: 10.1071/CP15217 
Panda, A. (2016). Exploring climate change perceptions, rainfall trends and perceived barriers to adaptation in a drought affected region in India. Nat. Hazards 84, 777-796. doi: 10.1007/s11069-016-2456-0

Pearce, D. W., and Turner, R. K. (1990). Economics of Natural Resources and the Environment. London: Harvester Wheatsheaf.

Peters, K., Breitsameter, L., and Gerowitt, B. (2014). Impact of climate change on weeds in agriculture: a review. Agron. Sustain. Dev. 34, 707-721. doi: 10.1007/s13593-014-0245-2

Pickett, J. A., Woodcock, C. M., Midega, C. A., and Khan, Z. R. (2014). Push-pull farming systems. Curr. Opin. Biotechnol. 26, 125-132. doi: 10.1016/j.copbio.2013.12.006

Power, A. G. (2010). Ecosystem services and agriculture: tradeoffs and synergies. Philos. Trans. R. Soc. B Biol. Sci. 365, 2959-2971. doi: 10.1098/rstb.2010.0143

Pradhan, P., Fischer, G., Velthuizen, H. V., Reusser, D. E., and Kropp, J. P. (2015). Closing yield gaps: how sustainable can we be? PLoS ONE 10:e0129487. doi: 10.1371/journal.pone.0129487

Prokopy, L. S., Carlton, J. S., Haigh, T., Lemos, M. C., Mase, A. S., and Widhalm, M. (2017). Useful to usable: developing usable climate science for agriculture. Clim. Risk Manage. 15, 1-7. doi: 10.1016/j.crm.2016.10.004

Rabotyagov, S., Kling, C. L., Gassman, P. W., Rabalais, N. N., and Turner, R. E. (2014). The economics of dead zones: causes, impacts, policy challenges, and a model of the Gulf of Mexico hypoxic zone. Rev. Environ. Econ. Policy 8, 58-79. doi: $10.1093 /$ reep/ret024

Ramesh, K., Matloob, A., Aslam, F., Florentine, S. K., and Chauhan, B. S. (2017). Weeds in a changing climate: vulnerabilities, consequences, and implications for future weed management. Front. Plant Sci. 8:95. doi: $10.3389 /$ fpls.2017.00095

Reynolds, M., and Langridge, P. (2016). Physiological breeding. Curr. Opin. Plant Biol. 31, 162-171. doi: 10.1016/j.pbi.2016.04.005

Richards, M., Bruun, T., Campbell, B., Gregersen, L., Huyer, S., Kuntze, V., et al. (2015). "How countries plan to address agricultural adaptation and mitigation," in CCAFS Info Note. CGIAR.

Robertson, G. P., and Swinton, S. M. (2005). Reconciling agricultural productivity and environmental integrity: a grand challenge for agriculture. Front. Ecol. Environ. 3, 38-46. doi: 10.1890/1540-9295(2005)003[0038:RAPAEI]2.0.CO;2

Romo, C. M., and Tylianakis, J. M. (2013). Elevated temperature and drought interact to reduce parasitoid effectiveness in suppressing hosts. PLOS ONE 8:e58136. doi: 10.1371/journal.pone.0058136

Sadras, V., Roget, D., and Krause, M. (2003). Dynamic cropping strategies for risk management in dry-land farming systems. Agric. Syst. 76, 929-948. doi: 10.1016/S0308-521X(02)00010-0

Sandor, J. A., Gersper, P. L., and Hawley, J. W. (1990). Prehistoric agricultural terraces and soils in the Mimbres area, New Mexico. World Archaeol. 22, 70-86. doi: $10.1080 / 00438243.1990 .9980130$

Sayre, K., and Govaerts, B. (2011). "Use of conservation agriculture to improve farming systems in developing countries," in Rainfed Farming Systems, eds P. Tow, I. Cooper, I. Partridge, and C. Birch (Dordrecht: Springer), 861-873.

Schaap, B. F., Reidsma, P., Verhagen, J., Wolf, J., and Van Ittersum, M. K. (2013). Participatory design of farm level adaptation to climate risks in an arable region in The Netherlands. Eur. J. Agron. 48, 30-42. doi: 10.1016/j.eja.2013.02.004

Schellhorn, N. A., MacFadyen, S., Bianchi, F., Williams, D. G., and Zalucki, M. P. (2008). Managing ecosystem services in broadacre landscapes: what are the appropriate spatial scales? Aust. J. Exp. Agric. 48, 1549-1559. doi: 10.1071/EA08112

Scherr, S. J., and McNeely, J. A. (2008). Biodiversity conservation and agricultural sustainability: towards a new paradigm of 'ecoagriculture' landscapes. Philos. Trans. R. Soc. B Biol. Sci. 363, 477-494. doi: 10.1098/rstb.2007.2165

Simelton, E., Fraser, E. D. G., Termansen, M., Benton, T. G., Gosling, S. N., South, A., et al. (2012). The socioeconomics of food crop production and climate change vulnerability: a global scale quantitative analysis of how grain crops are sensitive to drought. Food Sec. 4, 163-179. doi: 10.1007/s12571-012-0173-4

Singh, P., Sharratt, B., and Schillinger, W. F. (2012). Wind erosion and PM10 emission affected by tillage systems in the world's driest rainfed wheat region. Soil Tillage Res. 124, 219-225. doi: 10.1016/j.still.2012.06.009

Snyder, C. S., Bruulsema, T. W., Jensen, T. L., and Fixen, P. E. (2009). Review of greenhouse gas emissions from crop production systems and fertilizer management effects. Agric. Ecosyst. Environ. 133, 247-266. doi: 10.1016/j.agee.2009.04.021
Stewart, J., and Faught, W. (1984). Response farming of maize and beans at Kahumanu, Machos Traditional, Kenya: recommendations, yield expectations, and economic benefits. East Afr. Agric. For. J. 44, 29-56.

Stöckle, C. O., Donatelli, M., and Nelson, R. (2003). CropSyst, a cropping systems simulation model. Eur. J. Agron. 18, 289-307. doi: 10.1016/S1161-0301(02)00109-0

Stöckle, C. O, Higgins, S., Nelson, R., Abatzoglou, J., Huggins, D., Pan, W., et al. (2017). Evaluating opportunities for an increased role of winter crops as adaptation to climate change in dryland cropping systems of the U.S. Inland Pacific Northwest. Clim. Change. doi: 10.1007/s10584-017-1950-z. [Epub ahead of print]

Tàbara, J. D., and Chabay, I. (2013). Coupling human information and knowledge systems with social-ecological systems change: reframing research, education, and policy for sustainability. Environ. Sci. Policy 28, 71-81. doi: 10.1016/j.envsci.2012.11.005

Tilman, D. (1999). Global environmental impacts of agricultural expansion: the need for sustainable and efficient practices. Proc. Natl. Acad. Sci. U.S.A. 96, 5995-6000. doi: 10.1073/pnas.96.11.5995

Tomer, M. D., and Locke, M. A. (2011). The challenge of documenting water quality benefits of conservation practices: a review of USDA-ARS's conservation effects assessment project watershed studies. Water Sci. Technol. 64, 300-311. doi: $10.2166 /$ wst.2011.555

Tonnang, H. E. Z., Herve, B. D. B., Biber-Freudenberger, L., Salifu, D., Subramanian, S., Ngowi, V. B., et al. (2017). Advances in crop insect modelling methods-Towards a whole system approach. Ecol. Modell. 354, 88-103. doi: 10.1016/j.ecolmodel.2017.03.015

Tress, G., Tress, B., and Fry, G. (2004). Clarifying integrative research concepts in landscape ecology. Landsc. Ecol. 20, 479-493. doi: 10.1007/s10980-004-3290-4

Turner, P. A., Griffis, T. J., Lee, X., Baker, J. M., Venterea, R. T., and Wood, J. D. (2015). Indirect nitrous oxide emissions from streams within the US Corn Belt scale with stream order. Proc. Natl. Acad. Sci. U.S.A. 112, 9839-9843. doi: $10.1073 /$ pnas. 1503598112

Tyler, J. M., and Hatchett, J. H. (1983). Temperature influence on expression of resistance to Hessian fly - (Diptera, Cecidomyiidae) in wheat derived from Triticum tauschii. J. Econ. Entomol. 76, 323-326. doi: 10.1093/jee/76.2.323

Venugopal, P. D., and Dively, G. P. (2017). Climate change, transgenic corn adoption and field-evolved resistance in corn earworm. R. Soc. Open Sci. 4:170210. doi: 10.1098/rsos.170210

Veres, A., Petit, S., Conord, C., and Lavigne, C. (2013). Does landscape composition affect pest abundance and their control by natural enemies? A review. Agric. Ecosyst. Environ. 166, 110-117. doi: 10.1016/j.agee.2011.05.027

Voora, V. A., and Venema, H. D. (2008). The Natural Capital Approach: A Concept Paper. International Institute for Sustainable Development.

Waldo, S., Chi, J., Pressley, S. N., O’keeffe, P., Pan, W. L., Brooks, E. S., et al. (2016). Assessing carbon dynamics at high and low rainfall agricultural sites in the inland Pacific Northwest US using the eddy covariance method. Agric. For. Meteorol. 218-219, 25-36. doi: 10.1016/j.agrformet.2015.11.018

Walthall, C. L., Hatfield, J., Backlund, P., Lengnick, L., Marshall, E., Walsh, M., et al. (2012). Climate Change and Agriculture in the United States: Effects and Adaptation. USDA Technical Bulletin 1935. Washington, DC.

Wani, S. P., Rockstrom, J., and Oweis, T. Y. (2009). Rainfed Agriculture: Unlocking the Potential. Wallingford Oxfordshire: CABI.

Whitbread, A. M., Davoren, C., Gupta, V. V. S. R., Llewellyn, R., and Roget, D. (2015). Long-term cropping system studies support intensive and responsive cropping systems in the low rainfall Australian Mallee. Crop Pasture Sci. 66, 553-565. doi: 10.1071/CP14136

White, P. T., Wolf, K. J., Johnson-Maynard, J. L., Velez, J. J., and Eigenbrode, S. D. (2014). Secondary climate change education in the Pacific Northwest. Nat. Sci. Educ. 43, 85-93. doi: 10.4195/nse2014.01.0001

Wickson, F., Carew, A. L., and Russell, A. W. (2006). Transdisciplinary research: characteristics, quandaries and quality. Futures 38, 1046-1059. doi: 10.1016/j.futures.2006.02.011

Wigboldus, S., Klerkx, L., Leeuwis, C., Schut, M., Muilerman, S., and Jochemsen, H. (2016). Systemic perspectives on scaling agricultural innovations. A review. Agron. Sustain. Dev. 36:46. doi: 10.1007/s13593-016-0380-z

Wilcox, J., and Makowski, D. (2014). A meta-analysis of the predicted effects of climate change on wheat yields using simulation studies. Field Crops Res. 156, 180-190. doi: 10.1016/j.fcr.2013.11.008 
Yorgey, G. G., Hall, S. A., Allen, E. R., Whitefield, E. M., Embertson, N. M., Jones, V. P., et al. (2017). Northwest U.S. agriculture in a changing climate: collaboratively defined research and extension priorities. Front. Environ. Sci. 5:52. doi: 10.3389/fenvs.2017.00052

Ziska, L. H. (2016). The role of climate change and increasing atmospheric carbon dioxide on weed management: herbicide efficacy. Agric. Ecosyst. Environ. 231, 304-309. doi: 10.1016/j.agee.2016.07.014

Ziter, C., Robinson, E. A., and Newman, J. A. (2012). Climate change and voltinism in Californian insect pest species: sensitivity to location, scenario and climate model choice. Glob. Chang. Biol. 18, 2771-2780. doi: $10.1111 / j .1365-2486.2012 .02748 . x$
Conflict of Interest Statement: The authors declare that the research was conducted in the absence of any commercial or financial relationships that could be construed as a potential conflict of interest.

Copyright (c) 2018 Eigenbrode, Binns and Huggins. This is an open-access article distributed under the terms of the Creative Commons Attribution License (CC BY). The use, distribution or reproduction in other forums is permitted, provided the original author(s) or licensor are credited and that the original publication in this journal is cited, in accordance with accepted academic practice. No use, distribution or reproduction is permitted which does not comply with these terms. 